\title{
鋼モルタル板を用いた座屈拘束ブレースにおける \\ 芯材と拘束材のクリアランス調整工法に関する研究 \\ CLEARANCE ADJUSTMENT CONSTRUCTION FOR CORE PLATE AND RESTRAINING \\ PART OF THE BUCKLING-RESTRAINED BRACE USING STEEL MORTAR PLANKS
}

\author{
中村 慎 ${ }^{* 1}$, 藤 田正 則 $^{* 2}$, 岩田 衛*3
}

Makoto NAKAMURA, Masanori FUJITA and Mamoru IWATA

\begin{abstract}
The clearance of the buckling-restrained brace is a factor that has a significant influence on its failure mode and mechanical behavior. In this study, the clearance adjustment construction for the buckling-restrained brace using steel mortar planks is improved. Further, the clearance adjustment construction of partially pasting fluororesin sheets or butyl rubbers to a core plate or spacers is proposed. The requirements for workability, cost performance, reliability for fabrication, and structural performance for safety is examined. Finally, based on a comprehensive evaluation, it is verified that the practicality of the proposed clearance adjustment construction.
\end{abstract}

\section{Keywords : Buckling-restrained brase, Steel mortar plank, Clearance adjustment construction, Clearance adjustment material, performance evaluation 座屈拘束ブレース，鋼モルタル板，クリアランス調整工法，クリアランス調整材，性能評価}

\section{1. 序}

座屈拘束ブレース（以降, BRB という）とは, 軸方向力を伝達寸 る芯材が座屈しないよう外周を拘束材で補剛した部材である 1)，2）。 安定した復元力特性を有するため, 中低層建築物では耐震部材とし て, 超高層および高層建築物では制振部材として広く利用され, サ ステナブル建築にも利用されている。今日では, さまざまな断面形 状の芯材と拘束材の組合せが提案されており, いずれの形状でも BRB としての性能が実験的に確認されている例え将3)-77。

あわせて，設計における基本事項が鋼構造制振設計指針 1)や鋼構 造座屈設計指針 2)等で整理されている。設計上の配慮を要する項目 として, 拘束材や接合部の設計, 拘束材の局部破壊の防止, 適切な クリアランスの確保などが挙げられており, 中でも適切なクリアラ ンスの確保が BRBの性能に大きく影響することが指摘されている。 その值が大きすぎると芯材の一部で座屈モードの振幅が大きくなり， 局部変形が生じやすくなる。小さくなりすぎると圧縮時の芯材の体 積膨張で芯材と拘束材間に摩擦力が生じ, 圧縮力が上昇して拘束材 ごと部材座屈を生じる ${ }^{2)}$ 。その值の適切な設定，製作上の峳密な管 理が必要であり, BRB のクリアランスを対象とした研究も進められ

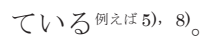

ただし，その具体的な值は BRB の形状，製作上の都合も勘案し て決定する必要があり，一概に設定することは難しい。現実にはさ
まざまな BRB で最適なクリアランスを個別に検討する必要があり， 各々の BRB でクリアランス調整工法や調整に用いる材料, 品質管 理手法を追究することが重要となる。

著者等はその一つとして，鋼モルタル板を用いた座屈拘束ブレー

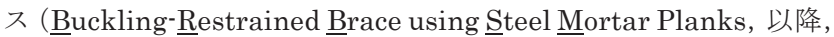
BRBSM という) に関寸る継続的な研究を行っている 7), 9)-15)。Fig.1 に示す拘束材となる 2 つの鋼モルタル板（溝形鋼にモルタルを充填 したもの）を両側にクリアランス調整材を貼付けた芯材に被せ，溶

(1) Clearance adjustmnet material (2) Core plate

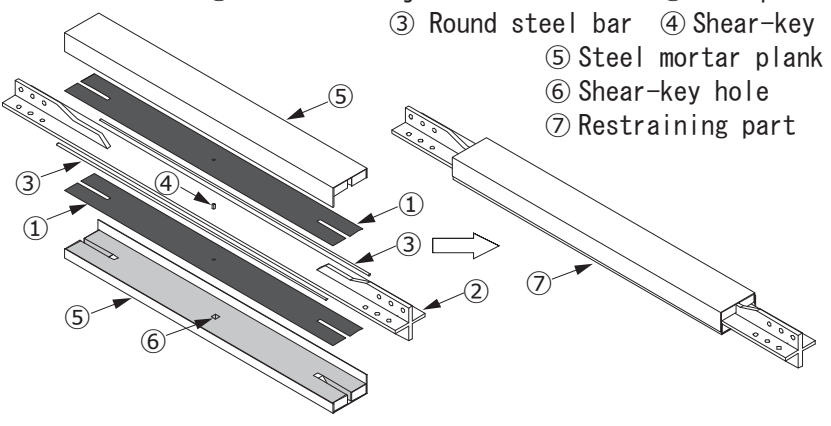

(Before assembling)

(After assembling)

Fig.1 Buckling-restrained braces using steel mortar planks
*1 神奈川大学工学部建築学科 助手 · 修士 (工学)

*2 神奈川大学工学部建築学科 教授・博士 (工学)

*3 神奈川大学 名誉教授. 工博
Research Assoc., Dept. of Architecture and Building Eng., Kanagawa Univ., M.Eng. Prof., Dept. of Architecture and Building Eng., Faculty of Eng., Kanagawa Univ., Dr.Eng. Prof. Emeritus, Dept. of Architecture and Building Eng., Kanagawa Univ., Dr.Eng. 
接により一体化したものである。芯材端部のディテールが拘束材よ り大きくなる場合においても，鋼モルタル板を後から挟み込む製作 手順となることから, 両端部ディテールの設計自由度が高い。また, 拘束材と芯材の併合前に拘束材のモルタル充填の程度, 平坦度, ク リアランスなどを目視で確認できるため, 品質管理を厳密に行える。

既往の研究では, BRBSM の各構成部をパラメータとした実験を 行い, 累積塑性歪エネルギー率についての性能評価下限式を提示し た 9)。また, 首都直下地震や長周期・長継続時間の地震動における 予想以上の地震入力に対応寸るため, 累積塑性歪エネルギー率の大 きな BRBSM の設計要件を分析し, 芯材形状, 幅厚比などの設計条 件を定めた ${ }^{13)}$ 。あわせて, BRBSM ではクリアランスをクリアラン ス比（芯材と拘束材の間のクリアランス寸法を芯材の板厚で除した 值）で管理している。最小のクリアランス比は最大軸歪に鋼材の塑 性時ポアソン比を乗じた值（最大軸歪 $3.0 \%$ におては $3.0 \% \times 0.5=$ $1.5 \%$ とし, 最大のクリアランス比は $15 \%$ 未満とすることを推奨し, その值を実現するクリアランス調整工法として，これまでにブチル ゴムを芯材全面に貼付ける工法を採用してきた。

ブチルゴムは芯材の位置を保持しつつ，モルタル表面の不陸にも 追従可能な硬度を有している。ロール状で市販されており, 芯材形 状にあわせた切断, 貼付けが可能でクリアランスを調整することが できる。一方で, 自己粘着力が強く, 一度貼付けるとその位置の調 整および貼替えが困難なため, 貼付け作業に時間を要すること, 圧 縮復元性が $100 \%$ でなく過度に加圧して塑性変形させると目標とす るクリアランス寸法を満たせなくなること, 押出機の吐出力の関係 上 $1 \mathrm{~mm}$ 以下の厚みでの安定した材料供給が難しく, より小さいクリ アランス比を実現するためには, モルタル表面の精密な平滑化処理 が必要不可欠になることといった製作性に関する課題を有している。

本論では, これらの製作性の課題のうち, 貼付けの作業性を改善 するクリアランス調整工法に関する検討を行う。まず, BRBSM の 種類と構成部品, クリアランス調整に用いる材料とその貼付け位置, 方法を整理し, クリアランス調整工法を分類する。次いで, クリア ランス調整工法の中から材料の総量や製作時間, コストに大幅な増 加がなく, 製作性の改善が期待できる工法とそれに対応した要求性 能を抽出し, 評価項目を設定する。設定したクリアランス調整工法 が従来のクリアランス調整工法と同等以上の性能を有することを実 験的に確認し, あわせて実例を踏まえた材料の総量および製作時間 に関する一検討も行い，その有効性について検討する。

\section{BRBSM におけるクリアランス調整工法 \\ 2.1 BRBSM の種類と構成部品}

BRBSM では芯材の形状の異なる基本タイプ (以降, B タイプと いう）と高性能タイプ（以降，H タイプという）の 2 種類が実用化

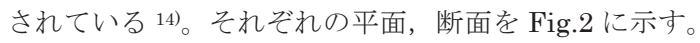

1) Bタイプ

B タイプは BRBSM の標準タイプである。芯材塑性化部の幅を一 定としており, クリアランス調整材の貼付けが容易で製作性に優れ る。拘束材に挟み込まれる芯材弱軸方向には表裏全面にクリアラン ス調整材を貼付けており, 強軸方向には丸鋼を配置している。両端 部のリブの断面と長さにより剛性を調節することができ, リブの長 さによって塑性化部の長さを調節できる。ただし，塑性化部の端部
にリブ溶接の熱影響部を有しており, その疲労性能は歪振幅 $1.0 \%$ 未 満の範囲で $\mathrm{H}$ タイプよりも小さくなる ${ }^{15)}$ 。っって, 主に風外力など による小振幅の繰返し載荷の影響が少ない中低層建築物に用いるブ レース (以降, 耐震ブレースという) としての利用を想定している。

2) $\mathrm{H}$ タイプ

$\mathrm{H}$ タイプはエネルギー吸収性能（累積塑性歪エネルギー率や疲労 性能）を高める目的で，芯材塑性化部の両端部に絞り（R 部）を設 け, 塑性化部からリブ溶接による熱影響部を無くしたタイプである。 芯材の弱軸方向は B タイプと同じく表裏全面にクリアランス調整 材を貼付けており，強軸方向の空いたスペースには変形を抑制する スペーサー（芯材厚と同じ鋼板）を配置している。 $\mathrm{R}$ 部の位置で塑 性化部の長さが調節可能であり，降伏耐力と軸剛性が調節し易い。 よって, 一般に中低層建築物よりも高いエネルギー吸収性能が求め られ, きめ細かい降伏耐力と軸剛性の調節が求められる時刻歴応答 解析を要寸る高層建築物等に用いるブレース（以降，制振ブレース という）としての利用を想定している。

\section{2 クリアランス調整工法の種類}

BRBSM の B タイプ, $\mathrm{H}$ タイプは芯材の形状, 構成部品に多少の 違いがあるものの, クリアランス調整に関しては共通してブチルゴ ムを芯材全面に貼付ける仕様としていた。

しかし, 製作性の改善に焦点を置くと, クリアランス調整材をブ チルゴムに限定する必要はなく, その貼付け面も芯材全面に限定す る必要はない。そこで，考えられるクリアランス調整材の貼付け位 置，貼付け方法とクリアランス調整に用いる材料の一例を抽出し， Fig.3 に示す。貼付け位置は芯材以外にもモルタル表面, 芯材強軸方 向に配置するスペーサー（丸鋼等）の表面などが考えられ，貼付け 方法は各々で全面に貼付けする，または部分的に貼付けすることが 考えられる。材料は 2 つの鋼モルタル板と芯材を重祮合わせ，溶接 で一体化するまでの間に芯材を一定の位置に保持できるものであれ ば採用できる可能性があり，代表的な建築材料を文献 16)から抽出 して示している。ただし，現実的に採用可能な材料は組立時に芯材 の位置保持が可能な硬度を有し，その一方で，地震力等による圧縮 力負担時にはポアソン比による体積膨張に適切に追従, 変形し,

L (Core plate length)

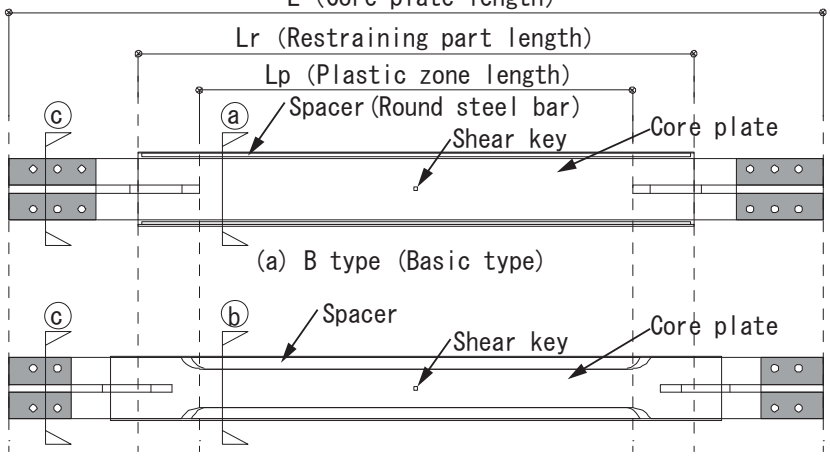

(b) $\mathrm{H}$ type (High-performance type)

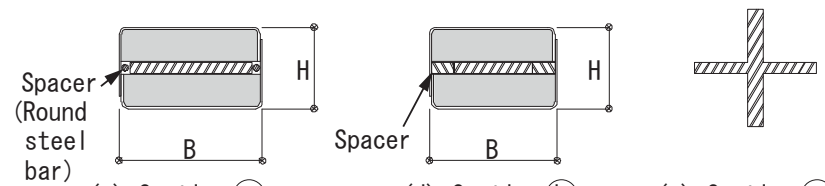

(c) Section a

(d) Section (b)

(e) Section (C)

Fig.2 Components of BRBSM 
座屈モード形成時における芯材と拘束材の接触時にも芯材と拘束材 間に過度な摩擦力を生じさせない硬度あるいは変形追従性, 低摩擦 性を有することが求められる。また, $1.0 \mathrm{~mm}$ 以下の精度で微調整が 可能な製作性，溶接で併合する際の熱に対する耐熱性なども求めら れるため, 例えば芯材と同材質の鋼材や $1.0 \mathrm{~mm}$ 以下の精度での微調 整に手間を要する石材, ガラスなどは採用するには不適である。

\section{3 クリアランス調整工法抽出のための予備実験}

本論では 2.2 で考えられる組合せのうち, 材料については従来の ブチルゴム以外に高分子材料の樹脂シート（フッ素樹脂シート）に 着目する。フッ素樹脂シートは従来のクリアランス調整でも使用寸 る金尺（直尺, 曲尺), カッターのみで切断が可能であり, 貼付け も手作業で行える。従来の工法と大差ない作業でクリアランス調整 が可能であり, 同等の製作性を実現できる可能性が高い。Fig.4に 抽出したクリアランス調整工法の模式図を示し, あわせて実施した 各工法の予備実験の結果を Table 1 に示す。予備実験は各工法の材

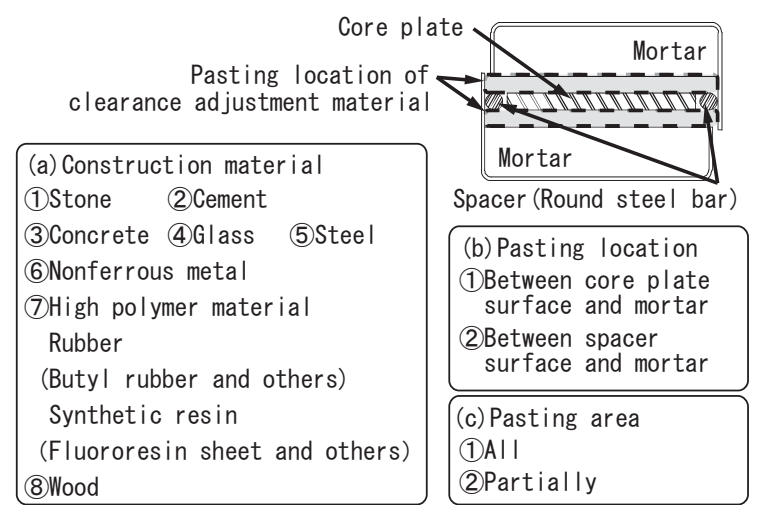

Fig.3 Clearance adjustment materials and setting location of BRBSM

$\begin{array}{r}\begin{array}{r}\text { Clearance } \\ \text { adjustment } \\ \text { Clearance material } \\ \text { adjustment } \\ \text { material location }\end{array} \\ \hline \begin{array}{l}\text { Between core } \\ \text { plate and mortar }\end{array} \\ \begin{array}{l}\text { Between spacer } \\ \text { (round steel bar) } \\ \text { and mortar }\end{array} \\ \hline \begin{array}{l}\text { Between spacer } \\ \text { (square steel bar) } \\ \text { and mortar }\end{array}\end{array}$

Fig.4 Clearance adjustment construction
料の総量, 製作時間, コストを検討する目的で実施し, 材料の切 断，貼付け，貼付けた材料の除去およびその再利用を Fig.5 に示す 範囲で検討している。なお, Table 1 ではクリアランス調整にかか る時間とコストをCase4 を基準に比率で示しており，材料単価は 2020 年 12 月時点での流通価格とし, ブチルゴムは 0.19 円 $/ \mathrm{cm}^{2}$, フッ素樹脂シートは $0.2 \mathrm{~mm}$ 厚で 0.50 円 $/ \mathrm{cm}^{2}, 1.0 \mathrm{~mm}$ 厚で 2.66 円 $/ \mathrm{cm}^{2}$ とし, 製作単価は国交省が示寸 2020 年 3 月から適用する公共 工事設計労務単価表 17)の普通作業員（東京）の単価 21,500 円を使 用し， 1 日の所定労働時間を 8 時間として計算する。

予備実験の範囲では，ブチルゴムを芯材を模した平板全面に貼付 けし，その縁に沿って材料を切断するだけの Case1 の製作時間が 最短となる。実際のクリアランス調整においては, 芯材が長く, 貼 付け面積が増大寸ること, 拘束材リブ付近や芯材中央のズレ止め付 近, $\mathrm{H}$ タイプにおいては塑性化部端部の $\mathrm{R}$ 部での切断, 貼付けに手 間を要するため, Case 1 と他の Case の製作時間の差はこれよりも 小さくなる。また, 前述の通り, ブチルゴムは自己粘着力が強く, 一度貼付るとその位置の調整及び貼替えが困難である。実際に予備 実験の範囲においても，工具を用いずに手作業でその全てを除去す ることは困難であり，除去した材料の再利用も不可能であった。

一方，フッ素樹脂シートを用いた Case $4 \sim 6$ では，フッ素樹脂シ 一トは簡単に除去でき，その再利用も可能である。位置の調整，貼 替えが容易であり，これまでの課題の改善が期待できる。ただし， フッ素樹脂シートを芯材を模した平板全面に貼付ける Case4 は, 予備実験の範囲でも材料にかかるコストがその他の Case の 7 倍以 上となり, コスト面でその他の Case に劣るため, 本論では検討か ら除く。従って, 本論では芯材または芯材の側面に配置するスペー サーにクリアランス調整材を部分的に貼付け，目標のクリアランス 比を満たす工法を抽出し, 検討する。

ブチルゴムを芯材全面に貼付ける従来のクリアランス調整工法を BA 工法とし，フッ素樹脂シートを芯材または芯材の側面に配置す るスペーサー (丸鋼, 角鋼) に部分的に貼付けるクリアランス調整 工法を FP工法とする。あわせて, ブチルゴムを芯材またはスペー

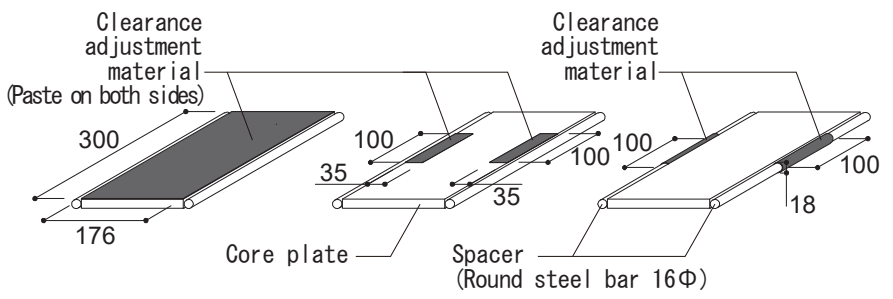
a) Specimen of
b) Specimen of
c) Specimen of

Fig.5 Preliminary experiment of clearance adjustment

Table 1 Results of preliminary experiments

\begin{tabular}{|c|c|c|c|c|c|c|c|c|c|c|c|c|c|}
\hline \multirow{3}{*}{$\begin{array}{l}\text { Preliminary } \\
\text { experiment }\end{array}$} & \multicolumn{5}{|c|}{ Clearance adjustment } & \multicolumn{4}{|c|}{ Production time } & \multicolumn{3}{|c|}{ Price ( Excluding removal ) } & \multirow{3}{*}{$\begin{array}{c}\text { Clearance } \\
\text { adjustment } \\
\text { material } \\
\text { reuse }\end{array}$} \\
\hline & \multicolumn{3}{|c|}{ Material } & \multirow[b]{2}{*}{$\begin{array}{l}\text { Pasting } \\
\text { Location }\end{array}$} & \multirow[b]{2}{*}{$\begin{array}{c}\text { Pasting } \\
\text { area }\end{array}$} & \multirow[b]{2}{*}{ Cutting } & \multirow[b]{2}{*}{ Pasting } & \multirow[b]{2}{*}{$\begin{array}{c}\text { Cutting } \\
+ \\
\text { Pasting }\end{array}$} & \multirow[b]{2}{*}{ Removal } & \multirow[b]{2}{*}{ Material } & \multirow[b]{2}{*}{ Production } & \multirow[b]{2}{*}{ Total } & \\
\hline & Type & $\begin{array}{c}\text { Thickness } \\
\mathrm{mm}\end{array}$ & $\begin{array}{c}\text { Adhesive } \\
\text { area } \\
\mathrm{cm}^{2}\end{array}$ & & & & & & & & & & \\
\hline Case1 & \multirow{3}{*}{$\begin{array}{l}\text { Butyl } \\
\text { rubber }\end{array}$} & 1.0 & 1056 & \multirow{2}{*}{ Core plate } & All & 0.27 & 0.20 & 0.23 & \multirow{3}{*}{ Difficult } & 0.07 & 0.23 & 0.08 & \multirow{3}{*}{ Impossible } \\
\hline Case2 & & 1.0 & 140 & & \multirow{2}{*}{ Partially } & 1.83 & 0.50 & 1.07 & & 0.01 & 1.07 & 0.05 & \\
\hline Case3 & & 1.0 & 110 & Spacer & & 1.50 & 0.75 & 1.07 & & 0.01 & 1.07 & 0.05 & \\
\hline Case4 & \multirow{3}{*}{$\begin{array}{c}\text { Fluororesin } \\
\text { sheet }\end{array}$} & 1.0 & 1056 & \multirow{2}{*}{ Core plate } & All & 1.00 & 1.00 & 1.00 & 1.00 & 1.00 & 1.00 & 1.00 & \multirow{3}{*}{ Possible } \\
\hline Case5 & & 1.0 & 140 & & \multirow{2}{*}{ Partially } & 1.67 & 1.00 & 1.29 & 1.33 & 0.13 & 1.29 & 0.17 & \\
\hline Case6 & & 0.2 & 540 & Spacer & & 1.08 & 1.25 & 1.18 & 1.20 & 0.10 & 1.18 & 0.13 & \\
\hline
\end{tabular}


サーに部分的に貼付けるクリアランス調整工法を BP 工法とし, 本 論ではブチルゴムの貼付け面積を減らしても BA 工法と同等以上の クリアランス調整が可能か確認すること， BP 工法と FP 工法で性 能に差が生じるか確認することを目的に, ブチルゴムを芯材に貼付 ける組合せを抽出して検討する。各工法の比較実験をもって, FP工 法, BP 工法で BA 工法と同等以上に BRBSM のクリアランス調整 が可能か確認する。

\section{4 クリアランス調整工法における要求性能}

2.2，2.3の検討をもとにBRBSM を製作する上でクリアランス調 整工法に求められる主な要求性能として, 以下の 4 点を抽出する。 1)製作性

クリアランス調整に要する製作の工数, 製作時間が少ないこと。 2)コスト（材料の総量および製作時間）

クリアランス調整に用いる材料の総量および製作時間が少なく, 低コストなクリアランス調整を実現すること。

\section{3)生産信頼性}

クリアランス調整の際の組立後のクリアランス比の平均值が推奨 值である $15 \%$ 未満に納まること。

4) 安全性（構造性能）

クリアランス調整の工法が BRBSM に求められる構造性能 (エネ ルギー吸収性能 (累積塑性歪エネルギー率) ), 安定した復元力特 性（圧縮引張耐力比等）を実現すること。

本論ではこれらの 4 つの要求性能を評価軸とし, 実験的な検討に よる定量的な評価を以って, FP 工法および BP 工法が BA 工法と同 等以上の性能を有することを確認する。

\section{3. 要求性能に対する比較実験}

\section{1 試験体の設定}

FP 工法, BP 工法と BA 工法の比較にあたり, B タイプと H タイ プの試験体を設定する。試験体一覧を Table 2 に，各試験体の平面
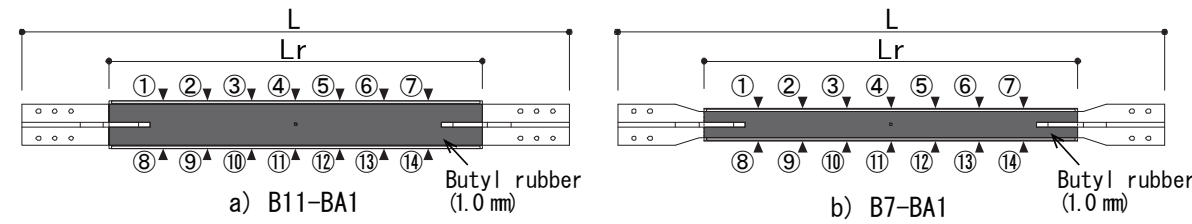

$L$

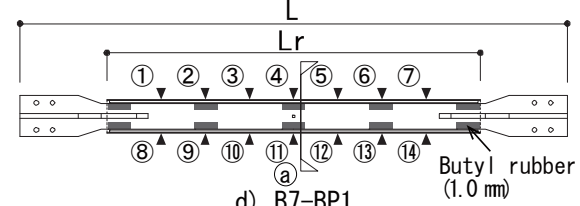

d) B7-BP1

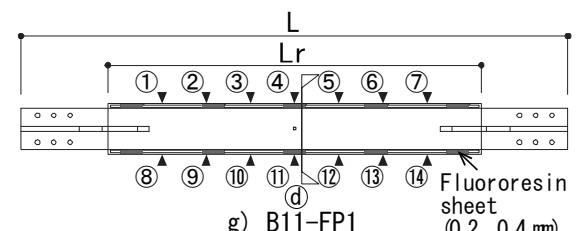

g) $\mathrm{B} 11-\mathrm{FP} 1$

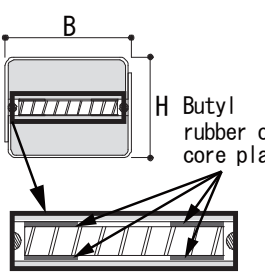

j) Section (a)

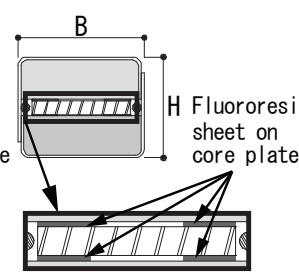

k) Section (b)

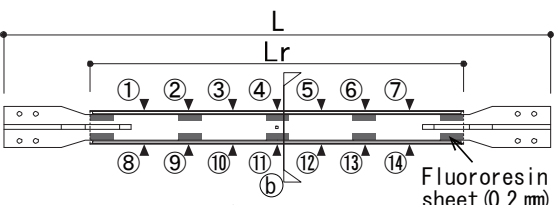

e) B7-FP1

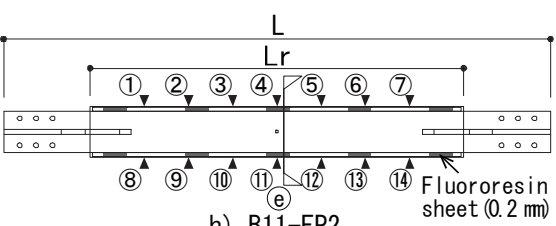

h) B11-FP2

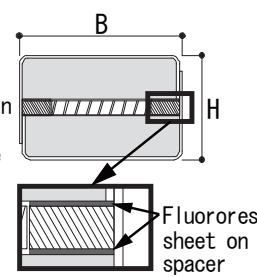

I) Section (C) m) Section (d)

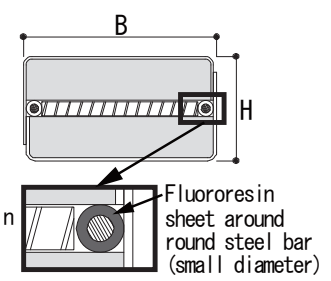

Fig.6 BRBSM specimens

Table 2 List of specimens

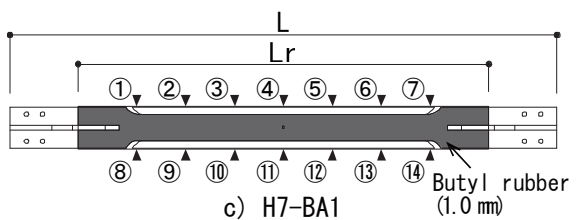

c) $\mathrm{H} 7-\mathrm{BA} 1$

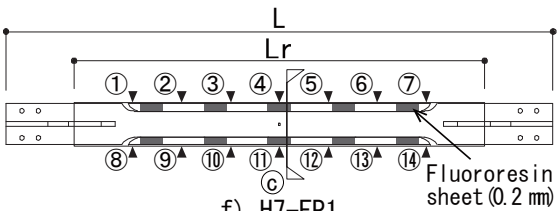

f) $\mathrm{H} 7-\mathrm{FP} 1$

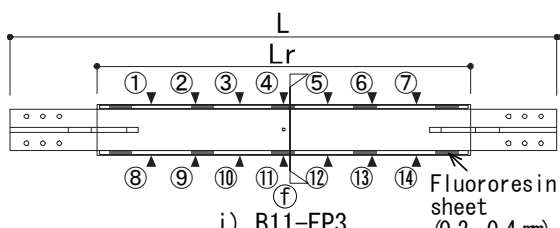

i) $\mathrm{B} 11-\mathrm{FP} 3$

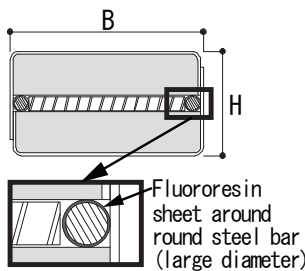

n) Section (e

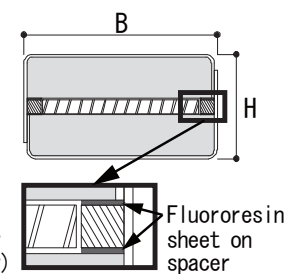

o) Section $f$

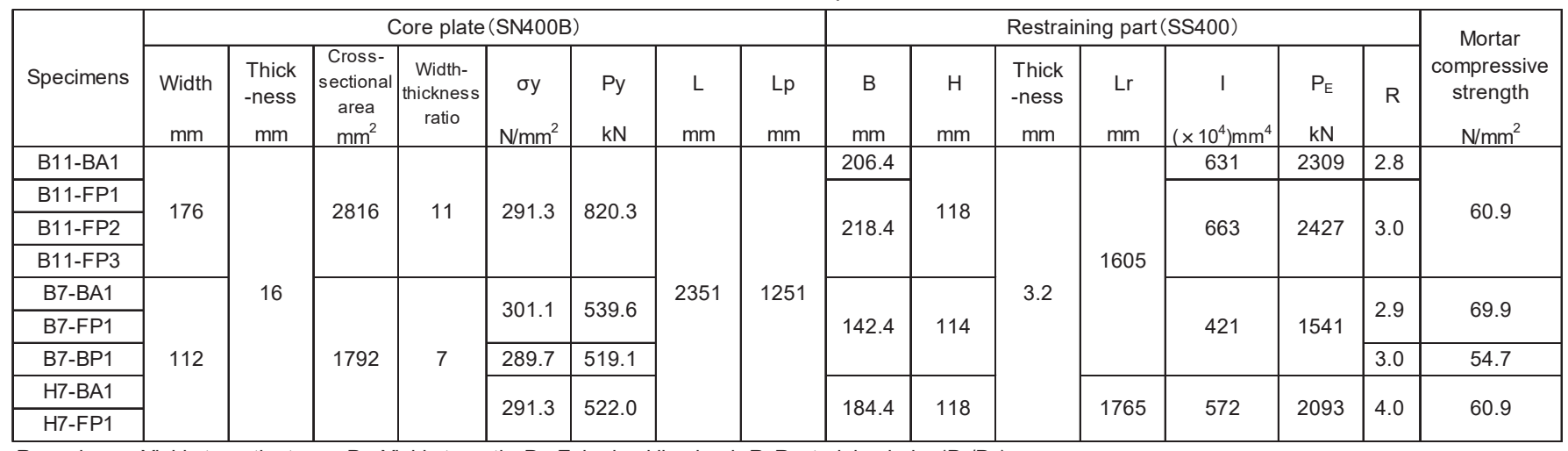

Remark: $\sigma y$ :Yield strength stress, Py: Yield strength, $\mathrm{P}_{\mathrm{E}}$ : Eular buckling load, $\mathrm{R}$ : Restraining index $\left(\mathrm{P}_{\mathrm{E}} / \mathrm{Py}\right)$ 
と断面を Fig.6 に示す。試験体名称は芯材のタイプ, 芯材の幅厚比, クリアランス調整工法, 数字の組合せとしており, 例えば B タイプ の幅厚比 11, BA 工法の試験体は B11-BA1, H タイプの幅厚比 7, $\mathrm{FP}$ 工法の試験体は H7-FP1 としている。芯材の鋼種は SN400B, 拘束材は SS400 とする。クリアランス調整材にはブチルゴム, フッ 素樹脂シートを採用寸る。

1) B タイプ試験体

$\mathrm{B}$ タイプの試験体は BA 工法によるものを 2 体, FP 工法による ものを 4 体，BP 工法によるものを 1 体製作する。

B11-BA1，B7-BA1 は芯材表裏全面にブチルゴムを貼付けた試験 体とし, B11-BA1 の芯材, 拘束材寸法などは既往の研究 10)の標準的 な試験体（S1，K1 試験体）に揃え，拘束指標 $\mathrm{R} \fallingdotseq 3.0$ とする。 $\mathrm{B} 7$ BA1 は, 芯材の塑性化部長さ, リブの長さと高さ, 拘束材へのリブ 貫入部長さを B11-BA1 に揃え, 芯材の幅厚比を H7-BA1 に揃えて いる。拘束材寸法は拘束指標 $\mathrm{R} \fallingdotseq 3.0$ になるよう設定寸る。芯材強 軸方向には各々，丸鋼を配置する。

B7-FP1，B7-BP1 は芯材の表裏に Fig.6に示寸通り，ブチルゴム またはフッ素樹脂シートを部分的に貼付けた試験体とする。1 か所 あたりのブチルゴムまたはフッ素樹脂シートのサイズは $30 \mathrm{~mm} \times$ $100 \mathrm{~mm}$ とし, 貼付け枚数は B7-FP1 で全ての位置で 2 枚, B7-BP1 で芯材中央部と端部が 2 枚, その他の位置が 1 枚とする。芯材, 拘 束材寸法などは B7-BA1 と揃え, 芯材強軸方向には各々, 丸鋼を配 置する点も同じとする。

B11-FP1，B11-FP2，B11-FP3 は芯材側面の丸鋼または角鋼にフ ッ素樹脂シートを巻付けまたは貼付ける試験体とする。芯材寸法は B11-BA1 と同一だが, フッ素樹脂シートを巻付けまたは貼付ける芯 材側面の丸鋼または角鋼の直径が増えるため，その分拘束材の幅を 増やしている。巻付けまたは貼付けの仕様は, B11-FP1 は丸鋼 10 $\phi に 0.4 \mathrm{~mm}$ 厚のフッ素樹脂シートを 7.5 回, その上に重放て $0.2 \mathrm{~mm}$ 厚のフッ素樹脂シートを 1.5 回巻付けている。B11-FP2 は丸鋼 16 $\phi に 0.2 \mathrm{~mm}$ 厚のフッ素樹脂シートを 2.5 回巻付けている。B11-FP3 は角鋼 $16 \times 16 \mathrm{~mm}$ の表に $0.4 \mathrm{~mm}$ 厚のフッ素樹脂シートを 1 枚, 裏 に $0.2 \mathrm{~mm}$ 厚のフッ素樹脂シートを 2 枚㙋付けている。巻付けまた は貼付けには市販の強力両面テープ $(0.23 \mathrm{~mm}$ 厚 $)$ を用い, それぞ れ両面テープの厚みも加算したクリアランス調整材の厚みで目標の クリアランス寸法を確保するよう計画する。

2) $\mathrm{H}$ タイプ試験体

$\mathrm{H}$ タイプの試験体は BA 工法によるもの，FP工法によるものを
各々 1 体製作する。芯材形状は B11-BA1 の形状をベースに芯材塑性 化部に絞り（R 部）を設けている。芯材強軸方向のディテールが $\mathrm{B}$ タイプとは異なるため, 拘束材の幅も必要最低限に減じている。

H7-BA1 は芯材表裏全面にブチルゴムを貼付けた試験体とし， H7-FP1 は芯材の側面に配置するスペーサーの表裏に $0.2 \mathrm{~mm}$ 厚の フッ素樹脂シートを 2 枚貼付けた試験体とする。

\section{2 製作性}

製作実験は試験体にクリアランス調整材を実際に貼付け，その工 数，製作時間等の比較を行う。クリアランス調整にかかる工数，製 作時間，コストの一覧をB11-BA1 を基準に比率とし, Table 3 に示 す。BA工法の試験体に着目すると，B11-BA1，B7-BA1 が H7-BA1 よりも製作にかかる時間に優れており，B タイプの製作に関する優 位性が数值化されている。

1) B タイプ試験体

$\mathrm{B}$ タイプにおける BP 工法, FP 工法と BA 工法の試験体を比較す ると BP 工法は材料の切断, 貼付けまたは巻付け時間とも減少して おり，貼付けまたは巻付け位置を限定することで，製作性が向上し ている。FP 工法は全ての試験体で貼付けまたは巻付けの時間が減 少しているが，材料の切断においては，B7-FP1，B11-FP2 が若干 の製作時間の減少となっており，B11-FP1，B11-FP3 については， 製作にかかる時間が増加した。これは複数の厚みのフッ素樹脂シー 卜を使用していること, それにより貼付けに要する両面テープの切 断回数が増えることによる。

2) $\mathrm{H}$ タイプ試験体

$\mathrm{H}$ タイプにおける BA工法および FP工法の試験体を比較すると, FP 工法の H7-FP1 が材料の切断および貼付けまたは巻付け時間と もに減少している。 $\mathrm{H}$ タイプは芯材塑性化部に絞り（R 部）を設け ていることで, BA 工法においても材料の切断回数が多くなる。従 って，B タイプと異なり，材料の切断においても FP 工法が製作性 に優れる結果となった。

以上より， B タイプの B7-BP1，B7-FP1，B11-FP2, H タイプの H7-FP1 で製作性の改善を確認し，BP 工法と FP 工法が， BA 工法 同等以上の製作性を実現できることを確認した。

\section{3 コスト（材料の総量および製作時間）}

BRBSM のコストはクリアランス調整に用いる材料の総量および 製作時間を用い, 実際にコストを算出して比較検討する。Table 3 に クリアランス調整に用いる材料の総量および製作時間, コストを B11-BA1 を基準に比率で示す。

Table 3 Economic performance for fabricating clearance adjustment material

\begin{tabular}{|c|c|c|c|c|c|c|c|c|c|c|c|c|c|}
\hline \multirow{3}{*}{ Specimens } & \multicolumn{3}{|c|}{ Clearance adjustment material } & \multicolumn{4}{|c|}{$\begin{array}{c}\text { Processing of clearance } \\
\text { adjustment material }\end{array}$} & \multicolumn{3}{|c|}{ Production time } & \multicolumn{3}{|c|}{ Price } \\
\hline & \multirow{2}{*}{ Materials } & \multirow{2}{*}{$\begin{array}{c}\text { Thickness } \\
\text { mm }\end{array}$} & \multirow{2}{*}{$\begin{array}{c}\text { Adhesive } \\
\text { area } \\
\mathrm{cm}^{2}\end{array}$} & \multicolumn{2}{|c|}{ Cutting } & \multicolumn{2}{|c|}{ Pasting } & \multirow{2}{*}{ Cutting } & \multirow{2}{*}{ Pasting } & \multirow{2}{*}{ Total } & \multirow{2}{*}{ Material } & \multirow{2}{*}{ Production } & \multirow{2}{*}{ Total } \\
\hline & & & & Number & Length & Number & Area & & & & & & \\
\hline B11-BA1 & Butyl rubber & 1.0 & 5491.8 & 1.00 & 1.00 & 1.00 & 1.00 & 1.00 & 1.00 & 1.00 & 1.00 & 1.00 & 1.00 \\
\hline B11-FP1 & \multirow{3}{*}{ Fluororesin sheet } & $0.2,0.4$ & 3950.0 & 1.21 & 0.62 & 5.63 & 0.72 & 2.55 & 0.75 & 1.31 & 4.29 & 1.31 & 2.56 \\
\hline B11-FP2 & & 0.2 & 1350.0 & 0.61 & 0.25 & 1.56 & 0.25 & 0.91 & 0.44 & 0.58 & 0.66 & 0.58 & 0.61 \\
\hline B11-FP3 & & $0.2,0.4$ & 450.0 & 1.64 & 0.64 & 1.88 & 0.08 & 2.46 & 0.39 & 1.03 & 0.33 & 1.03 & 0.74 \\
\hline B7-BA1 & Butyl rubber & 1.0 & 3437.4 & 1.00 & 0.96 & 1.00 & 0.63 & 0.95 & 0.93 & 0.93 & 0.63 & 0.93 & 0.80 \\
\hline B7-FP1 & Fluororesin sheet & 0.2 & 1200.0 & 1.50 & 0.55 & 2.50 & 0.22 & 0.89 & 0.50 & 0.62 & 0.58 & 0.62 & 0.60 \\
\hline B7-BP1 & \multirow{2}{*}{ Butyl rubber } & 1.0 & 1200.0 & 0.36 & 0.38 & 2.00 & 0.22 & 0.44 & 0.17 & 0.26 & 0.22 & 0.26 & 0.24 \\
\hline H7-BA1 & & 1.0 & 4339.4 & 1.14 & 0.94 & 1.00 & 0.79 & 1.59 & 1.42 & 1.47 & 0.79 & 1.47 & 1.18 \\
\hline H7-FP1 & Fluororesin sheet & 0.2 & 1200.0 & 1.50 & 0.55 & 2.50 & 0.22 & 0.89 & 0.47 & 0.60 & 0.58 & 0.60 & 0.59 \\
\hline
\end{tabular}


なお，材料単価，製作単価は 2.3 と同様とし，フッ素樹脂シートの $0.4 \mathrm{~mm}$ 厚は 2020 年 12 月時点での流通価格である 1.26 円 $/ \mathrm{cm}^{2}$ を用 いて計算し，一例を示す。

1) Bタイプ試験体

B タイプにおける FP 工法, BP 工法と BA 工法の試験体を比較すると B7-BP1，B7-FP1，B11-FP2，B11-FP3 でクリアランス調整にかかる 合計費用が減少している。B11-FP1については，1 か所あたりのク リアランス調整材の巻付け回数が多いこと, 複数の厚みを使用して いることなどが原因で材料費および製作費がともに増加している。 2) $\mathrm{H}$ タイプ試験体

$\mathrm{H}$ タイプにおける BA工法および FP工法の試験体を比較すると, $\mathrm{FP}$ 工法の H7-FP1 がクリアランス調整にかかる材料費, 製作費と もに減少している。とくに H7-FP1については, B タイプの B7-BA1 と比較しても材料費, 製作費ともに減少しており, FP工法を用いる ことで $\mathrm{H}$ タイプでも製作性に優れる $\mathrm{B}$ タイプと同等以上の製作性 を実現し，製作にかかるコストの低減が図れることを確認した。

\section{4 生産信頼性}

生産信頼性に関する実験は試験体を実際に組立てし, 組立後のク リアランス比の平均值を推奨值とした $15 \%$ 未満に納めることを確 認する。組立は特別な機器, 重機を使用せず, 人力で実施する。拘 束材の長さ方向の中央部と両端部の計 3 か所を $\mathrm{C}$ 字形の万力で同 程度に締付け, 加圧にて調整する。モルタル面の平滑度は組立後寸 法に影響しないよう，各試験体で同等に仕上げる。

クリアランスの計測位置を Fig.6に示す。(1)から (14)の片側 7 か所, 両側 14 か所とし, B タイプは拘束材中央から両側に各々 $190 \mathrm{~mm}$ ピ ッチで, H タイプは $210 \mathrm{~mm}$ ピッチで計測位置を設ける。計測内容 は Fig. 7 に示寸芯材厚 $\mathrm{t}$, スペーサー厚 $\mathrm{t}_{\mathrm{s}}$, 鋼モルタル板高さ $\mathrm{H}_{\mathrm{m} 1}$, $\mathrm{H}_{\mathrm{m} 2}$, 試験体組立後の $\mathrm{Ha}$ と組立前のクリアランス調整材の厚み $\mathrm{C}_{\mathrm{b}}$ とし，ノギスを用いて $0.01 \mathrm{~mm}$ 単位まで計測する。

各試験体の組立前（加圧調整前）のクリアランス比を芯材厚 $\mathrm{t}$, ク リアランス調整材を貼付けまたは巻付けする部品の厚み $\mathrm{t}_{1}$ (芯材 $\mathrm{t}$
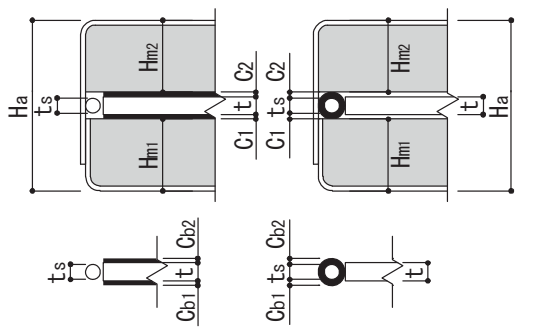

$t$ : Core plate thickness ts : Spacer thickness $\mathrm{H}_{\mathrm{m} 1}, \mathrm{H}_{\mathrm{m} 2}$ : Height of $\mathrm{Ha}$ : Height after assembly $\mathrm{Cb}: \mathrm{Cb}_{1}+\mathrm{Cb}_{2}$

$\mathrm{Cb}_{1}, \mathrm{Cb}_{2}$ : Clearance adjustment material thickness (Before assembly) $\mathrm{C}=\mathrm{Ha}-\left(\mathrm{t}+\mathrm{H}_{\mathrm{m} 1}+\mathrm{H}_{\mathrm{m} 2}\right)$ $\mathrm{C}=\mathrm{Ha}-\left(\mathrm{t}+\mathrm{Hm}_{\mathrm{m} 1}+\mathrm{H}_{\mathrm{m} 2}\right)$
$\mathrm{C}_{1}, \mathrm{C}_{2}$ : Clearance adjustment $\mathrm{c} / \mathrm{t}$ material thickness steel mortar plank $\mathrm{c} / \mathrm{t}$ : Clearance ratio

Fig.7 Contents of measurement
またはスペーサー厚 $\mathrm{ts}$ ), クリアランス調整材の厚み $\mathrm{Cb}_{\mathrm{b}}$ とあわせて Table 4 に示し, 組立後のクリアランス比を Table 5 に示す。組立前 のクリアランス比は $\mathrm{C}$ を $\mathrm{C}_{\mathrm{b}}+\mathrm{t} 1-\mathrm{t}$ で計算し, 組立後のクリアラン ス比は $\mathrm{C}$ を $\mathrm{Ha}-\left(\mathrm{t}+\mathrm{H}_{\mathrm{m} 1}+\mathrm{H}_{\mathrm{m} 2}\right)$ にて計算している。

試験体組立後のクリアランス比の平均值は全て推奨值以内に納ま っている。あわせて組立前後の值を比較すると, BA 工法で 0.69 か ら 0.80, FP 工法で 0.29 から 0.82, BP 工法で 0.36, クリアランス 比が小さくなっており, 各工法で最低でも $18 \%$, クリアランス比を 調整することができる。なお, B11-FP1 は 0.29, B7-BP1 は 0.36 と 組立後にクリアランス比が特に小さくなっているが，これは組立前 のクリアランス調整材の厚みが他の試験体よりも厚いこと, 部分貼 りではクリアランス調整材とモルタル表面の接触面も小さいため, 同程度に加圧して調整した際の縮み代が大きいことによる。

標準偏差を比較すると, BA 工法は 1.32\%から $2.18 \%$, BP 工法は 2.34\%, FP 工法は $1.04 \%$ から $2.28 \%$ となっており, バラツキの最大 值はほぼ同等の值となっている。以上より, FP工法, BP 工法でも, BA 工法と同等のクリアランス調整が可能である。

\section{5 安全性（構造性能）}

組立後の試験体を既往の研究と同様に水平載荷し，安全性（構造 性能）を確認する。

1)実験モデル

既往の研究 7) と同じくブレースの組込まれた中小建築物が水平力 を受け，せん断変形した場合を想定する。試験体の全長 $(2351 \mathrm{~mm})$ とその塑性化部長さ（1251mm）を考慮すると, 芯材に生じる軸方 向歪は層間変形角とほぼ等しくなる。すなわち, 中地震動に対応し て想定される層間変形角 $1 / 200$ 相当の芯材の軸方向歪は $0.50 \%$ とな り，大地震動に対応して想定される層間変形角 $1 / 100$ 相当の芯材の 軸方向歪は $1.00 \%$ となる。

Table 4 Clearance ratio before assembly

\begin{tabular}{|c|c|c|c|c|c|}
\hline \multirow[b]{2}{*}{ Specimens } & \multirow{2}{*}{$\begin{array}{c}\text { Clearance } \\
\text { ratio } \\
\% \\
\end{array}$} & \multicolumn{4}{|c|}{ Measured value } \\
\hline & & $\begin{array}{c}\mathrm{t} \\
\mathrm{mm}\end{array}$ & $\begin{array}{c}\mathrm{t}_{\mathrm{s}} \\
\mathrm{mm}\end{array}$ & $\begin{array}{c}\mathrm{t}_{1} \\
\mathrm{~mm}\end{array}$ & $\begin{array}{c}\mathrm{C}_{\mathrm{b}} \\
\mathrm{mm}\end{array}$ \\
\hline B11-BA1 & 12.42 & \multirow{6}{*}{16.10} & \multirow{2}{*}{10.00} & 16.10 & 2.00 \\
\hline B11-FP1 & 7.39 & & & 10.00 & 7.29 \\
\hline B11-FP2 & 7.02 & & 16.00 & 16.00 & 1.23 \\
\hline B11-FP3 & 8.32 & & 15.95 & 15.95 & 1.49 \\
\hline B7-BA1 & 12.42 & & \multirow{3}{*}{11.00} & 16.10 & 2.00 \\
\hline B7-FP1 & 10.68 & & & 16.10 & 1.72 \\
\hline B7-BP1 & 24.46 & 16.35 & & 16.35 & 4.00 \\
\hline H7-BA1 & 12.42 & \multirow{2}{*}{16.10} & 10.00 & 16.10 & 2.00 \\
\hline H7-FP1 & 7.27 & & 15.55 & 15.55 & 1.72 \\
\hline
\end{tabular}

Remark : t : Core plate thickness, ts : Spacer thickness

$t_{1}$ : Thickness of parts to which clearance adjustment material is pasted $\mathrm{C}_{\mathrm{b}}$ : Clearance adjustment material thickness

Table 5 Clearance ratio after assembly

\begin{tabular}{|c|c|c|c|c|c|c|c|c|c|c|c|c|c|c|c|c|c|}
\hline \multirow{3}{*}{ Specimens } & \multicolumn{16}{|c|}{ Clearance ratio $(\%)$} & \multirow{3}{*}{$\begin{array}{c}\text { Clearance ratio } \\
\text { ( after assembly } \\
\text { (average) / before } \\
\text { assembly ) }\end{array}$} \\
\hline & \multicolumn{14}{|c|}{ Measured position } & \multirow[b]{2}{*}{ Average } & \multirow{2}{*}{$\begin{array}{l}\text { Standard } \\
\text { deviation }\end{array}$} & \\
\hline & (1) & (2) & (3) & (4) & (5) & (6) & (7) & (8) & (9) & (10) & (11) & (12) & (13) & (14) & & & \\
\hline B11-BA1 & 11.46 & 13.08 & 10.72 & 10.90 & 10.34 & 9.91 & 6.29 & 12.77 & 10.40 & 8.29 & 7.48 & 7.29 & 8.41 & 6.98 & 9.60 & 2.08 & 0.77 \\
\hline B11-FP1 & 1.80 & 2.05 & 1.43 & 2.55 & 2.17 & 1.49 & 0.75 & 3.60 & 5.84 & 1.06 & 0.12 & 2.36 & 3.11 & 1.68 & 2.14 & 1.35 & 0.29 \\
\hline B11-FP2 & 6.21 & 5.09 & 5.28 & 5.84 & 6.09 & 3.91 & 3.48 & 4.78 & 3.66 & 4.16 & 2.73 & 3.60 & 4.84 & 5.47 & 4.65 & 1.04 & 0.66 \\
\hline B11-FP3 & 8.88 & 6.96 & 6.52 & 2.42 & 4.66 & 4.41 & 3.17 & 9.50 & 7.45 & 9.13 & 6.77 & 7.89 & 9.63 & 8.70 & 6.86 & 2.28 & 0.82 \\
\hline B7-BA1 & 10.53 & 12.21 & 11.96 & 9.42 & 7.99 & 10.10 & 8.05 & 10.84 & 14.93 & 11.34 & 7.68 & 6.51 & 10.16 & 7.81 & 9.97 & 2.18 & 0.80 \\
\hline B7-FP1 & 9.29 & 10.78 & 10.47 & 10.22 & 8.12 & 8.49 & 8.49 & 4.71 & 9.11 & 9.42 & 8.49 & 6.94 & 2.48 & 6.88 & 8.13 & 2.20 & 0.76 \\
\hline B7-BP1 & 9.72 & 11.56 & 8.81 & 7.34 & 9.66 & 9.05 & 3.98 & 10.21 & 7.58 & 7.16 & 10.03 & 13.09 & 8.69 & 4.77 & 8.69 & 2.34 & 0.36 \\
\hline H7-BA1 & 11.30 & 8.63 & 9.25 & 8.76 & 9.07 & 9.44 & 7.33 & 9.25 & 9.38 & 7.95 & 5.84 & 6.83 & 9.32 & 7.39 & 8.55 & 1.32 & 0.69 \\
\hline H7-FP1 & 3.79 & 5.59 & 5.65 & 8.88 & 5.40 & 5.09 & 4.47 & 3.17 & 3.48 & 4.41 & 4.35 & 4.66 & 3.23 & 1.74 & 4.57 & 1.59 & 0.63 \\
\hline
\end{tabular}




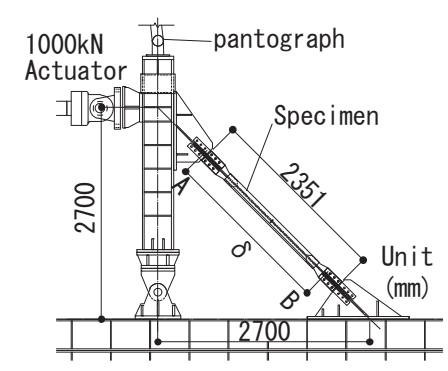

Fig.8 Loading equipment

Table 6 Loading cycles

\begin{tabular}{|c|c|c|}
\hline No & $\varepsilon(\%)$ & $\begin{array}{c}\text { Number } \\
\text { of loading }\end{array}$ \\
\hline 1 & $\varepsilon_{y} / 3$ & 1 \\
\hline 2 & $2 \varepsilon_{y} / 3$ & 1 \\
\hline 3 & 0.25 & 1 \\
\hline 4 & 0.50 & 2 \\
\hline 5 & 0.75 & 2 \\
\hline 6 & 1.00 & 5 \\
\hline 7 & 1.50 & 2 \\
\hline 8 & 2.00 & 2 \\
\hline 9 & 2.50 & 2 \\
\hline 10 & 3.00 & 2 \\
\hline
\end{tabular}

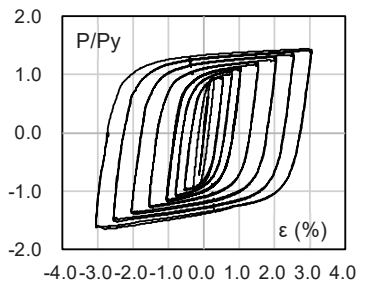

(a) B11-BA1

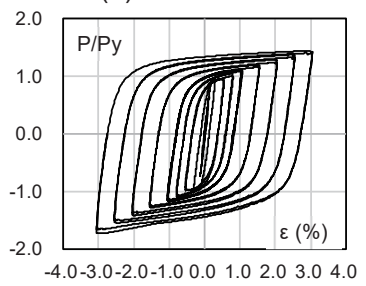

(d) B11-FP3

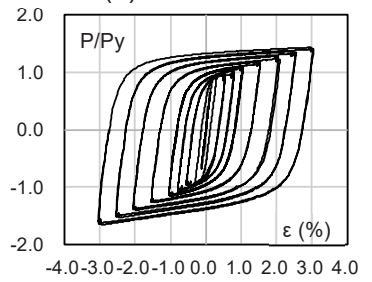

(g) B7-FP1

2)載荷方法

載荷装置を Fig. 8 に示す。試験体は 45 度の角度で設置し, 載荷柱 の柱脚部はピン支持, 柱頭部には面外方向の変形を拘束するための パンタグラフを設置する。加力は $1000 \mathrm{kN}$ アクチュエータを使用し, 軸方向変位制御による正負交番漸増繰返し載荷と寸る。載荷パター ンは既往の研究と同じく Table 6 としており, 本論では $3.0 \%$ 歪 2 回 目までの性能を確認する。なお, 所定の歪振幅において, 圧縮また は引張側の耐力が最大耐力の $80 \%$ まで低下, または引張破断した場 合はその時点で実験を終了する。試験体の軸方向変位 $\delta$ は, 芯材の 第一ボルト孔間(Fig.8, A B 間)の変位を試験体の両サイドに設置し た変位計で測定し, その平均值とする。

3)実験結果

各試験体の降伏耐力比 $\left(\mathrm{P} / \mathrm{P}_{\mathrm{y}}\right)$ と芯材の軸歪 $(\varepsilon=$ 軸変形量/塑性 化部長さ)の関係を Fig. 9 に示す。全ての試験体で $3.0 \%$ 歪 2 回目載 荷まで安定した復元力特性を示している。

次に, 各試験体の圧縮引張耐力比 $\alpha$ (各軸歪時における圧縮時の 最大耐力 $\mathrm{Pc}$ を引張時の最大耐力 $\mathrm{Pt}$ で除した值) を Fig. 10 に示す。 圧縮引張耐力比 $\alpha$ の值については, 現時点で明確な構造規定, 規・ 基準は存在せず，その上限や下限に関する決まりがない。ただし， その值が過度に上昇した場合, 例えば K 形ブレース付き骨組では引 張ブレースと圧縮ブレースの軸力差による鉛直力が梁に付加せん断 力として作用し, 設計時の想定を外れる恐れがある。ここで, 現行 の構造設計で考えると, 梁の継手部の強度確保には一般に保有耐力 接合が用いられる。保有耐力接合における安全率 $\alpha$ の最低值は継手 部の曲げ・せん断に対し, 400 ニュートン級炭素鋼で 1.2 倍, 490 二 ユートン級炭素鋼に対し，1.1 倍となる。本論ではこの值を参考と し， $\alpha=1.10$ 未満を設計に与える影響が少ない（仮に大梁に $490=$ ユートン級炭素鋼が用いられた場合でも, 付加せん断力が安全率の 中に収まる）值として比較，検討する。

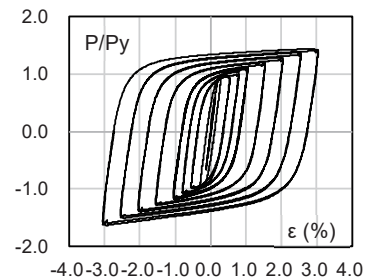

(b) B11-FP1

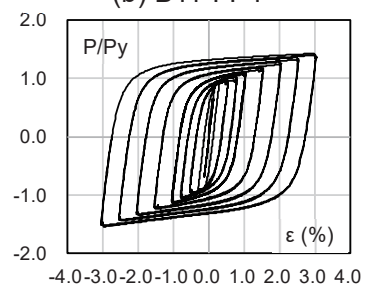

(e) B7-BA1

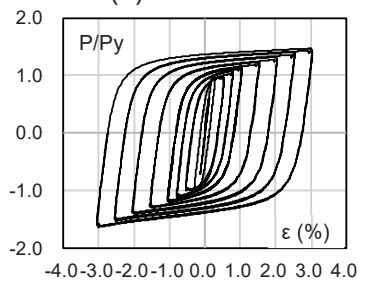

(h) H7-BA1

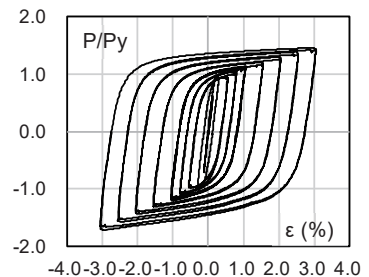

(c) B11-FP2

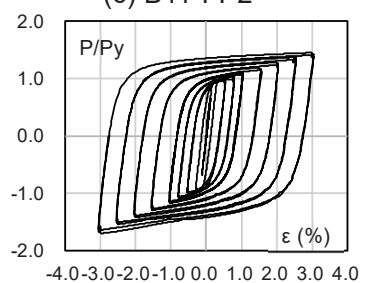

(f) B7-BP1

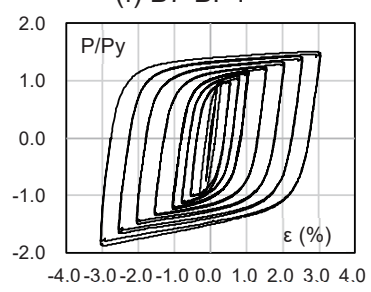

(i) H7-FP1
Fig.9 P/Py-strain curve

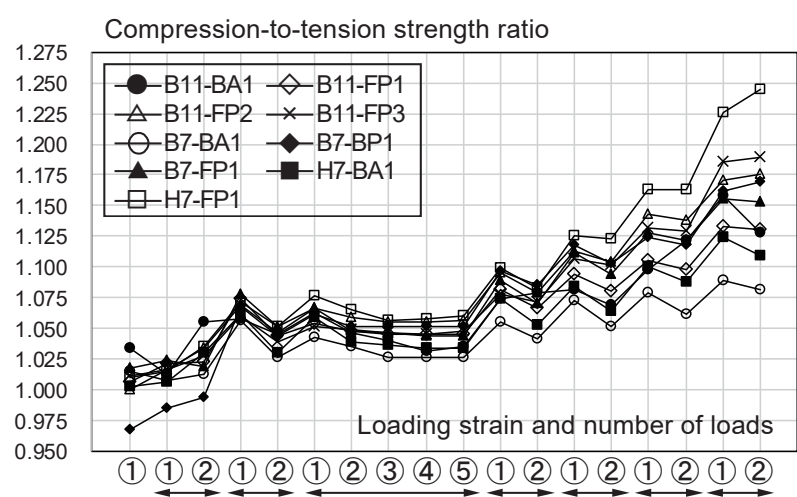

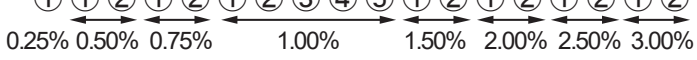

Fig.10 Compression-to-tension strength ratio

現行の構造設計で確認される層間変形角（令第 82 条の 2) $1 / 200$ 相当にあたる芯材の軸方向歪 $0.50 \%$ 時において, 各試験体の圧縮引 張耐力比 $\alpha$ は 1.055 から 0.985 となる。あわせて, 現行の構造設計 で確認される鉄骨造の大地震動時の層間変形角 $1 / 100$ 相当にあたる 芯材の軸方向歪 1.00\%時において, 圧縮引張耐力比 $\alpha$ は 1.026 から 1.077 となる。それぞれ, 1.10 未満となり, FP工法, BP 工法も実 用上で問題ないものと考える。

なお, 個別の試験体ごとに確認すると, B11-FP1 はクリアランス 比の最小值で推奨值 $(1.5 \%)$ を下回る箇所があるが, その圧縮引張 耐力比 $\alpha$ は他の FP 工法の值と同等か, それ以下となる。これは, 推奨值を下回った計測位置の対となる計測位置（11)に対して (4), (7) に対して(14)）のクリアランス比が推奨值を満たすため, 同一断面で クリアランスが完全に閉塞せず, 過度な摩擦力が生じなかったため と考える。また, H7-FP1 は軸方向歪 $2.50 \%$ 以上で他の試験体より も顕著に圧縮引張耐力比 $\alpha$ が上昇した。これは芯材塑性化部の両端 部の $\mathrm{R}$ 部とリブ先端部までの間に無補剛区間（I 形断面）があるこ 
とによる。 $\mathrm{P} / \mathrm{Py}$ - 関係によると, $2.5 \%$ 歪 1 回目の圧縮側で $\mathrm{P} / \mathrm{Py}$ の值が 1.59 となり, I 形断面と塑性化部の断面積の比率（幅厚比 11 / 幅厚比 $7 \fallingdotseq 1.57)$ を上回る。本論ではこの部位にクリアランス調整 材を設けていないため, この部位に塑性化が生じた際, 座屈モード の進展等による芯材とモルタル面の摩擦が生じ, 圧縮力が上昇した ものと考える。

最後に, 累積塑性歪エネルギー率 $\omega$ と拘束指標 R の関係を Fig. 11 に示す。 $\omega$ は復元力特性から算出した累積塑性歪エネルギーEt を芯 材の降伏荷重 $\mathrm{P}_{\mathrm{y}}$ と弾性限界変形量 $\delta_{\mathrm{y}}$ を乗じた值 $\mathrm{Wy}$ で除した無次 元化量であり, 拘束指標 $\mathrm{R}$ は拘束材のオイラー座屈荷重 $\mathrm{P}_{\mathrm{E}}$ を芯材 の降伏荷重 $\mathrm{P}_{\mathrm{y}}$ で除した值である。Fig.11 には既往の研究 9)で提案し た性能評価下限式（ $\omega \mathrm{r}=150 \times \mathrm{R}(\mathrm{R} \leqq 6))$ もあわせて示している。 各試験体とも性能評価下限值を上回る性能を示しており, エネルギ 一吸収性能についても, BP 工法および FP 工法で BA 工法とほぼ同 等の性能を実現することが可能である。

\section{6 総合評価}

製作性，コスト(材料の総量および製作時間), 生産信頼性, 安全性 (構造性能)の検討結果をもとに総合評価を行う。本論における評価 基準は以下の通り設定する。

1)製作性

3.2 で検討したクリアランス調整に要する製作時間の合計を用い, その值の逆数とする。

2)コスト（材料の総量および製作時間）

3.3 で検討したクリアランス調整材のコストの合計を用い，その 值の逆数とする。

3)生産信頼性

3.4 で検討した試験体組立後のクリアランス比の平均值が品質管 理上の推奨值（15.0\%）を上回る場合には推奨值（15.0\%）を試験 体組立後のクリアランス比の平均值で除して用いる。下回る場合 には 1.00 とする。

4)安全性（構造性能）

3.5 で検討した各試験体の累積塑性歪エネルギー率 $\omega$ が性能評価 下限值を上回る場合 1.00 とし, 各試験体の累積塑性歪エネルギー 率 $\omega$ が性能評価下限值を下回る場合は各試験体の累積塑性歪エネ ルギー率 $\omega$ を性能評価下限值 $\omega \mathrm{r}$ で除して用いる。

なお，総合評価においては，製作性，コスト，生産信頼性，安全 性（構造性能）の各項目に対し，使用する状況に応じた重み係数を 乗じることが適切と考えるが, 重み係数は使用寸る状況に左右され， 一概に決定することが困難である。従って, 本論では重み係数はそ れぞれ 1.00 とし, 総合評価の評価点は各項目の評価点を単純累加寸 ることで算出する。

総合評価の結果を Table 7 に示す。本論の評価では B タイプにつ いて B7-BP1，H タイプについて H7-FP1, 全試験体において B7$\mathrm{BP} 1$ が最も優れた評価となった。ともに製作性, コストが従来の BA 工法よりも向上し, 安全性（構造性能）においても従来の BA 工法 と同等の構造性能を有することを確認している。また， B タイプの FP 工法に着目すると, B11-FP2, B7-FP1 が H タイプの H7-FP1 とほぼ同等の評価になっている。よって, 本論で検討した FP工法, BP 工法は従来の BA 工法と同様に耐震, 制振ブレースの製作に用 いることが可能なクリアランス調整工法であると考える。

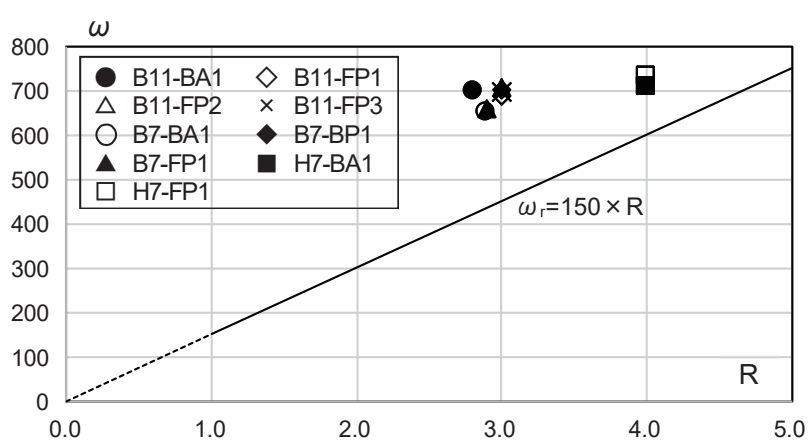

Fig. 11 Cumulative plastic strain energy ratio and restraining index

Table 7 Comprehensive evaluation

\begin{tabular}{|c|c|c|c|c|c|}
\hline Specimens & Workability & Cost & Reliability & $\begin{array}{c}\text { Structural } \\
\text { safety }\end{array}$ & $\begin{array}{c}\text { Compre } \\
\text {-hensive } \\
\text { evaluation }\end{array}$ \\
\hline B11-BA1 & 1.00 & 1.00 & 1.00 & 1.00 & 4.00 \\
\hline B11-FP1 & 0.76 & 0.39 & 1.00 & 1.00 & 3.15 \\
\hline B11-FP2 & 1.72 & 1.64 & 1.00 & 1.00 & 5.36 \\
\hline B11-FP3 & 0.97 & 1.35 & 1.00 & 1.00 & 4.32 \\
\hline B7-BA1 & 1.08 & 1.25 & 1.00 & 1.00 & 4.33 \\
\hline B7-BP1 & 3.85 & 4.17 & 1.00 & 1.00 & 10.01 \\
\hline B7-FP1 & 1.61 & 1.67 & 1.00 & 1.00 & 5.28 \\
\hline H7-BA1 & 0.68 & 0.85 & 1.00 & 1.00 & 3.53 \\
\hline H7-FP1 & 1.67 & 1.69 & 1.00 & 1.00 & 5.36 \\
\hline
\end{tabular}

\section{4. 実例を踏まえた材料の総量および製作時間に関する一検討}

BA 工法の BRBSM で施工された建物のクリアランス調整工法を FP 工法，BP 工法に置き替えた場合を想定し，材料の総量および製 作時間に関する一検討を行う。 3.3 の検討結果から求めたクリアラ ンス調整の製作に関する単価を Table 8 に示す。BA 工法はロール 状のブチルゴムを芯材に必要なだけ送り出して貼付け, 都度カット する製作手順を取ることから，切断時間と貼付け時間およびその合 間の時間を厳密に分けることが困難となる。よって, ここでは製作 にかかる合計の単価のみ示している。以降，本単価を利用して実案 件を踏まえた材料の総量および製作時間に関する一検討を行う。

\subsection{B タイプの BRBSM を用いた鉄骨造中層建築物}

BA 工法（B11-BA1 と同一のクリアランス調整工法）の採用され た鉄骨造（一部 RC 造），地上 5 階，延べ面積約 $11,500 \mathrm{~m}^{2}$ の建物で 検討する。BRBSM リス卜をTable 9 に示す。想定建物の BRBSM のクリアランス調整工法を BA 工法から FP 工法, BP 工法に置き替 えた場合のコストを比較する。検討は BA 工法を想定したケースで B11-BA1 の製作単価を, FP 工法を想定したケースで B11-FP3 の製 作単価を，BP 工法を想定したケースで B7-BP1 の製作単価を各々 使用する。また，材料単価は $2.3 ， 3.3$ で用いた 2020 年 12 月時点 での流通価格を使用する。検討結果を Table 10 に示す。検討結果は BA 工法を基準に比率で示している。 BP 工法とした場合，材料費が 0.11 , 製作費が 0.14 , 合計費用が 0.13 まで低減し, FP 工法とした 場合, 材料費が 0.43 , 製作費が 0.81 , 合計費用が 0.65 に低減する。 $\mathrm{B}$ タイプのクリアランス調整において，FP工法， BP 工法とも，コ ストの削減が可能であることを確認した。

\section{$4.2 \mathrm{H}$ タイプの BRBSM を用いた鉄骨造超高層建築物}

BA工法 (H7-BA1 と同一のクリアランス調整工法)の地上 22 階,

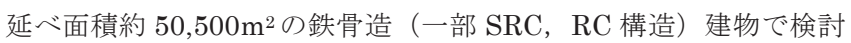


Table 8 Price for fabricating clearance adjustment material

\begin{tabular}{|c|c|c|c|}
\hline \multirow{2}{*}{ Specimens } & \multicolumn{3}{|c|}{ Price $\left(\right.$ yen $\left./ \mathrm{cm}^{2}\right)$} \\
\cline { 2 - 4 } & Cutting & Pasting & Total \\
\hline B11-BA1 & - & - & 0.25 \\
\hline B11-FP1 & 0.28 & 0.18 & 0.46 \\
\hline B11-FP2 & 0.29 & 0.31 & 0.60 \\
\hline B11-FP3 & 2.37 & 0.84 & 3.20 \\
\hline B7-BA1 & - & - & 0.38 \\
\hline B7-BP1 & 0.16 & 0.14 & 0.30 \\
\hline B7-FP1 & 0.32 & 0.40 & 0.72 \\
\hline H7-BA1 & - & - & 0.47 \\
\hline H7-FP1 & 0.32 & 0.38 & 0.70 \\
\hline
\end{tabular}

Table 9 BRBSM lists of the mid-rise steel building

\begin{tabular}{|c|c|c|c|c|c|c|c|c|c|}
\hline \multirow[b]{2}{*}{ Members } & \multicolumn{4}{|c|}{ Core plate } & \multicolumn{4}{|c|}{ Restraining part } & \multirow[b]{2}{*}{ Quantity } \\
\hline & $\begin{array}{c}\text { Width } \\
\mathrm{mm}\end{array}$ & $\begin{array}{c}\text { Thick } \\
\text {-ness } \\
\text { mm }\end{array}$ & Py & L & $\begin{array}{c}\mathrm{H} \\
\mathrm{mm}\end{array}$ & $\begin{array}{c}\text { B } \\
\mathrm{mm}\end{array}$ & $\begin{array}{c}\text { Thick } \\
\text {-ness } \\
\mathrm{mm}\end{array}$ & Lr & \\
\hline V1 & 96 & 16 & 500 & 3.3 & 140 & 186 & 6 & 2.6 & 34 \\
\hline V2 & 144 & 16 & 750 & 3.5 & 140 & 190 & 9 & 2.8 & 47 \\
\hline V2A & 144 & 16 & 750 & 3.9 & 140 & 196 & 12 & 3.2 & 12 \\
\hline V3 & 162 & 19 & 1000 & 3.5 & 140 & 220 & 12 & 2.8 & 8 \\
\hline V3A & 162 & 19 & 1000 & 3.6 & 150 & 214 & 9 & 2.9 & 8 \\
\hline V4 & 202 & 19 & 1250 & 3.6 & 150 & 254 & 9 & 2.8 & 12 \\
\hline V4A & 202 & 19 & 1250 & 3.9 & 170 & 254 & 9 & 3.0 & 1 \\
\hline V11 & 96 & 16 & 500 & 3.6 & 150 & 186 & 6 & 2.9 & 26 \\
\hline V12 & 144 & 16 & 750 & 3.6 & 150 & 184 & 6 & 2.9 & 15 \\
\hline V12A & 144 & 16 & 750 & 4.0 & 150 & 190 & 9 & 3.3 & 19 \\
\hline V13 & 162 & 19 & 1000 & 3.7 & 150 & 214 & 9 & 3.0 & 22 \\
\hline V13A & 162 & 19 & 1000 & 4.1 & 150 & 220 & 12 & 3.4 & 10 \\
\hline V14 & 202 & 19 & 1250 & 3.7 & 150 & 254 & 9 & 2.9 & 8 \\
\hline
\end{tabular}

Table 10 Cost evaluation of the mid-rise steel building

\begin{tabular}{|c|c|c|c|c|c|}
\hline \multirow{2}{*}{$\begin{array}{c}\text { Clearance } \\
\text { adjustmnnt } \\
\text { construction }\end{array}$} & \multicolumn{2}{|c|}{ Clearance adjustmnnt } & \multicolumn{3}{|c|}{ Price } \\
\cline { 2 - 6 } & Material & $\begin{array}{c}\text { Quantity } \\
\mathrm{m}^{2}\end{array}$ & Material & Production & Total \\
\hline BA & $\begin{array}{c}\text { Butyl rubber } \\
(1.0 \mathrm{~mm})\end{array}$ & 182.2 & 1.00 & 1.00 & 1.00 \\
\hline FP & $\begin{array}{c}\text { Fluororesin sheet } \\
(0.4 \mathrm{~mm})\end{array}$ & 11.6 & 0.43 & 0.81 & 0.65 \\
\hline BP & $\begin{array}{c}\text { Butyl rubber } \\
(1.0 \mathrm{~mm})\end{array}$ & 20.5 & 0.11 & 0.14 & 0.13 \\
\hline
\end{tabular}

Table 11 BRBSM lists of the super-high-rise steel building

\begin{tabular}{|c|c|c|c|c|c|c|c|c|c|}
\hline \multirow[b]{2}{*}{ Members } & \multicolumn{4}{|c|}{ Core plate } & \multicolumn{4}{|c|}{ Restraining part } & \multirow[b]{2}{*}{ Quantity } \\
\hline & $\begin{array}{c}\text { Width } \\
\mathrm{mm}\end{array}$ & $\begin{array}{c}\text { Thick } \\
\text {-ness } \\
\text { mm }\end{array}$ & $\begin{array}{l}\text { Py } \\
\text { kN }\end{array}$ & $\mathrm{m}$ & $\mathrm{mm}$ & $\begin{array}{c}\text { B } \\
\mathrm{mm}\end{array}$ & $\begin{array}{c}\text { Thick } \\
\text {-ness } \\
\mathrm{mm}\end{array}$ & $\mathrm{Lr}$ & \\
\hline BR10 & 168 & 28 & 1000 & 3.3 & 180 & 300 & 9 & 2.30 & 12 \\
\hline BR15 & 209 & 32 & 1500 & 3.3 & 184 & 357 & 9 & 2.10 & 16 \\
\hline BR20 & 247 & 36 & 2000 & 3.3 & 198 & 411 & 9 & 2.20 & 29 \\
\hline BR25 & 278 & 40 & 2500 & 3.8 & 264 & 460 & 9 & 2.60 & 52 \\
\hline BR30 & 334 & 40 & 3000 & 4.5 & 334 & 516 & 9 & 3.20 & 42 \\
\hline
\end{tabular}

Table 12 Cost evaluation of the super-high-rise building

\begin{tabular}{|c|c|c|c|c|c|}
\hline \multirow{2}{*}{$\begin{array}{c}\text { Clearance } \\
\text { adjustmnnt } \\
\text { construction }\end{array}$} & \multicolumn{2}{|c|}{ Clearance adjustmnnt } & \multicolumn{3}{|c|}{ Price } \\
\cline { 2 - 6 } & Material & $\begin{array}{c}\text { Quantity } \\
\mathrm{m}^{2}\end{array}$ & Material & Production & Total \\
\hline BA & $\begin{array}{c}\text { Butyl rubber } \\
(1.0 \mathrm{~mm})\end{array}$ & 265.8 & 1.00 & 1.00 & 1.00 \\
\hline FP & $\begin{array}{c}\text { Fluororesin sheet } \\
(0.4 \mathrm{~mm})\end{array}$ & 65.6 & 1.68 & 0.37 & 0.74 \\
\hline BP & $\begin{array}{c}\text { Butyl rubber } \\
(1.0 \mathrm{~mm})\end{array}$ & 26.0 & 0.10 & 0.06 & 0.07 \\
\hline
\end{tabular}

する。BRBSM リストを Table 11 に示す。

以下， 4.1 と同様に BRBSM のクリアランス調整工法を BA 工法 から FP 工法, BP 工法に置き替えた場合のコストを比較する。検討 は BA 工法を想定したケースで H7-BA1 の製作単価を，FP 工法を 想定したケースで H7-FP1 の製作単価を，BP 工法を想定したケー スで B7-BP1 の製作単価を各々使用する。材料単価は $2.2,2.3$ で用 いた 2020 年 12 月時点での流通価格を使用する。検討結果を Table12 に示寸。検討結果は BA 工法を基準に比率で示している。

FP 工法を採用した場合，材料費は 0.68 増加しているが，製作費 が 0.63 , 合計のコストが 0.26 低減し, $\mathrm{H}$ タイプのクリアランス調 整においてもコスト削減が可能であることを確認した。BP 工法と した場合，材料費が 0.10 ，製作費が 0.06 ，合計費用が 0.07 まで低 減することを確認した。 4.1 および 4.2 の検討より, FP工法, BP工 法は BRBSM のタイプによらず，コストの削減が期待できることを 確認した。

\section{5. 結}

本論では鋼モルタル板を用いた座屈拘束ブレースを対象に，製作 性の課題のうち, 貼付けの作業性を改善するクリアランス調整工法 に関する検討を行い, 以下の知見を得た。

1） FP 工法, BP 工法で BA 工法と同等以上に座屈拘束ブレースの クリアランスを調整することが可能である。座屈拘束ブレース のクリアランス調整においては, クリアランス調整材を必ずし も芯材全面に貼付ける必要はなく，芯材の一部，または芯材周 囲のスペーサー（丸鋼または角鋼）に貼付け，適切にクリアラ ンスを確保することで BA工法と同等以上の製作性, コスト（材 料の総量および製作時間), 生産信頼性, 安全性（構造性能）を 実現できる。

2） FP 工法のうち製作性に最も優れるのは，太径の丸鋼にフッ素 樹脂シートを 1 回巻付ける工法であり, 試験体 B11-FP2 となる。

3） FP 工法のうちコスト（材料の総量および製作時間）に最も優 れるのは, スペーサーにフッ素樹脂シートを貼付ける工法であ り，試験体 H7-FP1 となる。

4）生産信頼性において, FP 工法, BP 工法で BA 工法と同様に推 奨值のクリアランス比 $15 \%$ を満たすことができる。

5）安全性（構造性能）において，FP 工法，BP 工法，BA 工法は ほぼ同等となり，いずれのクリアランス調整工法を用いても耐 震，制振ブレースとして使用できる性能を有する。

6）クリアランス調整工法に対する要求性能として，製作性，コス 卜（材料の総量および製作時間）, 生産信頼性，安全性（構造性 能）を総合評価した結果，Bタイプは B7-BP1，H タイプは H7FP1 が優れている。

7）実例を踏まえた材料の総量および製作時間に関する一検討に おいては， BA 工法を FP 工法に置き替えることで，クリアラ ンス調整にかかる製作費を B タイプで $19 \%$ ，H タイプで $63 \%$ 低減することができる。同様に BA 工法を BP 工法に置き替え ることで,クリアランス調整にかかる製作費を B タイプで $86 \%$, H タイプで $94 \%$ 低減することができる。 


\section{謝辞}

本実験の試験体の計画，製作にあたり，有限会社 ISBT の村井正 敏氏にご協力頂きました。また, 本実験の遂行にあたり, 神奈川大 学工学部建築学科教務技術職員の佐藤宏貴氏, 神奈川大学大学院生 の㴰澤裕貴氏にご協力頂きました。ここに記して深謝いたします。

\section{参考文献}

1) Architectural Institude of Japan : Recommended Provisions for Seismic Damping Systems applied to Steel Structures, 2014.11

日本建築学会編 : 鋼構造制振設計指針, 2014.11

2) Architectural Institude of Japan : AIJ Recommendations for Stability Design of Steel Structures, 2018.2

日本建築学会編 : 鋼構造座屈設計指針, 2018.2

3) Fujimoto M., Wada A., Saeki E., Watanabe A., Hitomi Y. : A STUDY ON THE UNBONDED BRACE ENCASED IN BUCKLINGRESTRAINING CONCRETE AND STEEL TUBE, Journal of Structural Engineering, Vol.34B, pp.249-258, 1988.3

藤本盛久, 和田章, 佐伯英一郎, 渡辺厚, 人見泰義 : 鋼管コンクリートに より座屈を拘束したアンボンドブレースに関する研究，構造工学論文集， Vol.34B, pp.249-258, 1988.3

4) Imai K., Yakiyama K., Tada M., Kuwahara S., Yoneyama T : A study on the stiffening effect of the Double Tube (Part.1 The procedure of the longitudinal loading test), Summaries of Technical Papers of Annual Meeting, Architectural Institute of Japan, Structures- II , pp.1281-1282, 1991.7

今井克彦, 脇山広三, 多田元英, 桑原進, 米山隆也 : 二重鋼管の補剛効果 に関寸る研究（その 1 、軸方向加力実験方法），日本建築学会大会学術講 演梗概集，構造-II , pp.1281-1282，1991.7

5) Takeuchi T., Suzuki K., Marukawa T., Kimura Y., Ogawa T., Sugiyama T., Kato S : PERFORMANCES OF COMPRESSIVE TUBE MEMBERS WITH BUCKLING RESTRAINER COMPOSED OF MORTAL INFILLED STEEL TUBE, Journal of Structural and Construction Engineering (Transactions of AIJ) , No.590, pp.71-78, 2005.4 竹内徹，鈴木一弁，丸川智輝，木村祥裕，小河利行，杉山武，加藤史郎： モルタル充填鋼管により座屈拘束された圧縮鋼管部材の変形性能, 日本建 築学会構造系論文集，第 590 号, pp.71-78, 2005.4

6) Jhon Alexander Segura Mateus, Tagawa H., Xingchen Chen : Bucklingrestrained brace using round steel bar cores restrained by inner round steel tubes and outer square steel tube, Engineering Structures, Vol.197, 15, 109379, 2019.10

7) Murai M., Kobayashi F., Noda T., Iwata M. : Experimental Study on Buckling-restrained Braces Using Steel MortarPlanks, Journal of Structural and Construction Engineering (Transactions of AIJ), No.569, pp.105-110, 2003.7

村井正敏, 小林史興, 野田隆博, 岩田衛 : 鋼モルタル板を用いた座屈拘束 ブレースの実験的研究, 日本建築学会構造系論文集, 第 569 号, pp.105$110,2003.7$

8) Yoshida K., Nishizawa H., Kishikawa I. : PROPER RANGE OF CLEARANCE FOR THE DESIGN OF THE BUCKLING RESTRAINED BRACE COVER, Journal of Structural Engineering, Vol.64B, pp.237$241,2018.3$

吉田競人, 西澤秀喜, 岸川樹生 : 座屈拘束ブレース拘束材設計式のための 適切な間隙, 構造工学論文集, Vol.64B, pp.237-241, 2018.3

9) IWATA Mamoru, MURAI Masatoshi : Buckling-restrained brace using steel mortar planks -performance evaluation as a hysteretic damper-, EARTHQUAKE ENGINEERING AND STRUCTURAL DYNAMICS, pp.1807-1818, 2006

10) Iwata M., Murase R. , Izumita Y, Murai M. : Experimental Study on Buckling-restrained Braces Using Steel MortarPlanks -Part3 Buckling behavior of the core plate-, Journal of Structural and Construction Engineering (Transactions of AIJ) , No.611, pp.133-139, 2007.1 岩田衛, 村瀬亮, 和泉田洋次, 村井正敏 : 鋼モルタル板を用いた座屈拘束 ブレースの実験的研究一その 3 芯材の座屈挙動一, 日本建築学会構造系 論文集，第 611 号，pp.133-139，2007.1
11) Murase R. , Murai M. , Iwata M. : Experimental Study on Bucklingrestrained Braces Using Steel MortarPlanks -Part4 Effects on core plate width-thickness ratio, restraining force and cross section details-, Journal of Structural and Construction Engineering (Transactions of AIJ) , No.620, pp.117-124, 2007.10

村瀬亮，村井正敏，岩田衛：鋼モルタル板を用いた座屈拘束ブレースの実 験的研究一その 4 芯材幅厚比と拘束力および断面ディテールの影響一, 日本建築学会構造系論文集, 第 620 号, pp.117-124, 2007.10

12)Midorika M. , Sasaki D. , Asari T. , Murai M. , Iwata M. : Experimental Study on Buckling-restrained Braces Using Steel MortarPlanks -Effects of the clearance between core plate and restraining member on compressive strength and estimation of the number of buckling mode related to compressive strength-, Journal of Structural and Construction Engineering (Transactions of AIJ), Vol.75, No.653, pp.1361-1368, 2010.7

緑川光正，佐々木大輔，麻里哲広，村井正敏，岩田衛：鋼モルタル板を用 いた座屈拘束ブレースの実験的研究ークリアランスの圧縮耐力への影響と 圧縮耐力に応じた座屈モード数の評価, 日本建築学会構造系論文集, 第 75 巻, 第 653 号, pp.1361-1368, 2010.7

13)Iizuka R., Koyano K. , Midorika M. , Iwata M. : Study on Bucklingrestrained Braces Having Large Cumulative Plastic Strain Energy Ratio, Journal of Structural and Construction Engineering (Transactions of AIJ) , Vol.79, No.701, pp.1015-1023, 2014.7

飯塚亮太，小谷野一尚，緑川光正，岩田衛 : 累積塑性歪エネルギー率の大 きな座屈拘束ブレースの研究, 日本建築学会構造系論文集, 第 79 巻, 第 701 号, pp.1015-1023，2014.7

14)Koyano K. , Miyagawa K. , Koide S. , Kitamura W. , Iwata M. : Study on the Buckling-restrained Brace Having High Fatigue Performance, AIJ Journal of Technology and Design, Vol.21, No.47, pp.137-140, 2015.2 小谷野一尚, 宮川和明, 小出秀一, 喜多村亘, 岩田衛 : 疲労性能の高い座 屈拘束ブレースの研究，日本建築学会技術報告集，第 21 巻，第 47 号, pp.137-140, 2015.2

15)Koyano K., Tadao N. , Midorika M. , Iwata M. : FATIGUE PERFORMANCE OF THE BUCKLING-RESTRAINED BRACE USING STEEL MORTAR PLANKS, Journal of Structural and Construction Engineering (Transactions of AIJ), Vol.82, No.736, pp.921-928, 2017.6 小谷野一尚, 中込忠男, 緑川光正, 岩田衛 : 鋼モルタル板を用いた座屈拘 束ブレースの疲労性能の研究, 日本建築学会構造系論文集, 第 82 巻, 第 736 号, pp.921-928, 2017.6

16)Architectural Institude of Japan : Kenchikuzairyouyoukyouzai (Teaching material for Construction materials) , 1990.3 日本建築学会編 : 建築材料用教材, 1990.3

17) Ministry of Land, Infrastructure, Transport and Tourism Homepage, Accessed 2021.3, https://www.mlit.go.jp/report/press/content/001328 838.pdf, accessed 2021.3.5 国土交通省ホームページ (令和 2 年 3 月から適用する公共工事設計労務 単価について)，参照 2021.3.5 


\author{
Makoto NAKAMURA ${ }^{* 1}$,Masanori FUJITA ${ }^{* 2}$ and Mamoru IWATA ${ }^{* 3}$ \\ ${ }^{*} 1$ Research Assoc., Dept. of Architecture and Building Eng., Kanagawa Univ., M.Eng. \\ * 2 Prof., Dept. of Architecture and Building Eng., Faculty of Eng., Kanagawa Univ., Dr.Eng. \\ ${ }^{*}$ Prof. Emeritus, Dept. of Architecture and Building Eng., Kanagawa Univ., Dr.Eng.
}

The clearance between the core plate and mortar of the buckling-restrained brace is a factor that has a significant influence on its failure mode status and mechanical behavior. The buckling-restrained brace using steel mortar planks (BRBSM) have been put into practical use in two types, the basic type (B type) and the high-performance type (H type), which have different core plate shapes. In both cases, the butyl rubber is pasted to the entire surface of the core plate as the clearance adjustment material (BA construction). This material has excellent constructability, but it has the disadvantage of being difficult to move after being pasted because it has a strong adhesive force.

In this study, the clearance adjustment construction for a BRBSM is improved. Using fluororesin sheets in addition to butyl rubbers, we propose a construction wherein a clearance adjustment material is pasted to a part of the core plate or spacers to facilitate attachment. Further, the workability, cost performance, reliability for fabrication, and structural performance for the safety of the proposed clearance adjustment construction using fluororesin sheets (FP construction) or butyl rubbers ( BP construction) are examined through construction and structural tests. In a comprehensive evaluation, the proposed clearance adjustment constructions are compared and examined. The following results are obtained.

1) The clearance of the buckling-restrained brace can be adjusted through the FP or BP construction equal to or better than that of the BA construction. When adjusting the clearance of the buckling-restrained brace, pasting the clearance adjustment material to the entire surface of the core plate is not always necessary. The results confirmed that the workability, cost performance, reliability for fabrication, and structural performance for safety benchmarks could be realized.

2) The FP construction with the best workability is the one wherein fluororesin sheets is wound once around a largediameter round steel bar (B11-FP2) .

3) The FP construction with the best cost performance is the one wherein fluororesin sheets is pasted to the spacer (H7-FP1) .

4) The reliability for fabrication is almost the same for FP, BP, and BA constructions. BRBSM that satisfies the recommended value of $15 \%$ can be manufactured.

5)The structural performance for safety is almost the same for FP, BP, and BA constructions, and each have a performance that can be used as earthquake-resistant and seismic-response-controlled braces.

6)The result of a comprehensive evaluation of the workability, cost performance, reliability for fabrication, and structural performance for the safety as the required performance for the clearance adjustment construction indicate that $\mathrm{B} 7-\mathrm{BP} 1$ is the best $\mathrm{B}$ type and $\mathrm{H} 7-\mathrm{FP} 1$ is the best $\mathrm{H}$ type.

7) By replacing the BA construction with the FP construction considering the building steel structure, the fabrication price for clearance adjustment can be reduced by $19 \%$ for the B type and $63 \%$ for the $\mathrm{H}$ type. Similarly, by replacing the BA construction with the BP construction, the fabrication price for clearance adjustment can be reduced by $86 \%$ for the B type and $94 \%$ for the $\mathrm{H}$ type. 